PostPrint of Berthele, R. (2012). On the Use of PUT Verbs by Multilingual Speakers of Romansh. In A. Kopecka \& B. Narasimhan (eds.), Events of "putting" and "taking": A crosslinguistic perspective., pp. 145-166. Amsterdam, Philadelphia: John Benjamins. p. 1

\title{
On the use of PUT Verbs by multilingual speakers of Romansh
}

\section{Raphael Berthele University of Fribourg}

In this chapter, the multilingual systems of bilingual speakers of Sursilvan Romansh and German are analyzed. The Romansh and the German systems show important differences in the domain of placement. Romansh has a fairly general verb metter 'to put' whereas German uses different verbs (e.g., setzen 'to set', legen 'to lay', stellen 'to stand'). Whereas there are almost no traces of German in the Romansh data elicited from the German-Romansh bilinguals, it appears that their production of German yields uses of the verbs which differ from the typical German system. Although the forms of the German verbs have been acquired by the bilingual speakers, their distribution in the data arguably reflects traces of the Romansh category of metter 'to put'.

\section{Introduction ${ }^{1}$}

In this chapter, a small partition of the multilingual mental lexicon of bi- or multilingual speakers of Romansh and German is described. The main goal of the study is twofold: Firstly, the two quite distinct ways of carving up the semantic space of PUTTING found in the two languages will be discussed. PUTTING in the remainder of this section refers to the way the two languages construe the placement of an object at a location. Secondly, the section aims to investigate the coexistence of these two spatial construals within one multilingual mind. The basic question in this study is whether the two ways of categorizing show any crosslinguistic interactions at all, and if so, what the exact nature and direction of these interactions is. The two systems will not be described extensively but rather in a selective way, which will allow us to concentrate on the parts where the two native language systems are most distinct.

The chapter is organized as follows: first, the Romansh language ecology will be presented briefly (Section 2). Secondly, some basic theoretical assumptions will be laid out (Section 3). In Section 4, the relevant parts of the semantic field in Sursilvan Romansh and German (Swiss, Standard High) will be discussed. The following section (5) then focuses on the German production of the bilingual speakers of Sursilvan and shows the particularities of this system. The final section (6) sums up the analyses carried out and shows how to integrate them into the general picture of language, minority culture, and the bilingual mind.

\section{Languages and informants}

All the informants for this study are native speakers of Sursilvan Romansh. Romansh is an umbrella term for a group of endangered Romance varieties spoken 
PostPrint of Berthele, R. (2012). On the Use of PUT Verbs by Multilingual Speakers of Romansh. In A. Kopecka \& B. Narasimhan (eds.), Events of "putting" and "taking": A crosslinguistic perspective., pp. 145-166. Amsterdam, Philadelphia: John Benjamins. p. 2 by about 40,000 people in the eastern Alps of Switzerland (Solèr, 1997; Cathomas, 2005; Liver, 1999). There are at least 5 different types of Romansh (“idioma”) with their respective written standards, and since the 1980s there is a standard language, Rumantsch Grischun, which is an attempt to help the language survive through a common written language, especially for official purposes, lawmaking, and textbooks. There is a long history of immigration of Germanic dialects into the traditionally Romansh territories since the 15th century, and there is no doubt that Romansh is a highly endangered language. All speakers today are bilinguals in Romansh and in German (Furer, 1985: 2; Cathomas, 2005: 154), although the exact nature of this bilingualism is hardly ever assessed or specified in the literature (cf. Section 6 for discussion). Since the goal of this investigation is to contrast the German and Sursilvan systems, we wanted to investigate the most fluent and proficient Romansh speakers we could find (i.e. sequentially bilingual subjects, see below). But even in the case of our speakers, their status as a small ethno-linguistic minority makes it inevitable for any Romansh to be a proficient speaker of German, since only an extremely limited number of public services operate in Romansh and there is neither higher education nor university with Romansh as the medium of instruction.

Despite the threatened status of the language, in some areas there are still schools which start (almost) exclusively in Romansh, and most of the informants in our sample went through such Romansh schools (for an overview of the different schooling models, cf. Cathomas 2005). Most of our informants grew up in a predominantly Sursilvanspeaking environment, and went to Sursilvan schools up to 6 th grade. German as a foreign language is taught from the 4th grade on. However, this does not mean that the informants learned German only at school, since, as described above, the Romansh territories are undergoing a rapid "Germanization", due to the local tourism industry and the immigration of German-speaking people. Most of our informants can be described as 'sequentially' rather than simultaneously bilingual (Romaine, 1995: 183) But since German is, economically and culturally, the increasingly more dominating language, there is no doubt that all of our speakers of Romansh have had early and rather intensive contact with German. In most cases, our informants still live in communities where Romansh is quite strongly supported by a larger local community. In some cases however, German has become the dominant language in the home villages of the respective informants, which entails that at least some of our informants should rather be included in Romaine's (1995: 184) bilingualism type 3, i.e. "non-dominant home language without community support”. 
PostPrint of Berthele, R. (2012). On the Use of PUT Verbs by Multilingual Speakers of Romansh. In A. Kopecka \& B. Narasimhan (eds.), Events of "putting" and "taking": A crosslinguistic perspective., pp. 145-166. Amsterdam, Philadelphia: John Benjamins. p. 3

Table 1. Languages and Informants

$\mathrm{L}$

\# informants

$\begin{array}{lr}\text { Romontsch Sursilvan L1 (fieldworker: Silvana Derungs) } & 13 \\ \text { German L2 (Swiss German dialects/Standard High) } & 12 \\ \text { German (Standard) L1 } & 6 \\ \text { German (Swiss German dialects) L1 } & 6\end{array}$

Table 1 gives an overview of the informants in the analysed sample. All data have been collected using the "put and take" video clips (Bowerman et al., 2004).

In Fall 2004, Silvana Derungs, a native speaker of Sursilvan, collected 13 data sets from the best native speakers of Romansh Sursilvan she could find. About 4 to 6 months later, we did a second collection with 12 out of these 13 informants, this time in German (the sociolinguistically unmarked choice is Swiss German, sometimes informants preferred to do the task in Standard High German).

In order to compare the Romansh system and the German production data of the Romansh to monolingual native German, I additionally collected a small set of data from informants speaking Swiss German (6) and Standard High German (6) (cf. Table 1). Since all informants in our sample are multilinguals to a certain extent, it is not correct to divide them into two groups of "monolinguals" vs. "bi- or multilinguals". The most precise way would be to speak of German-dominant multilinguals and Romansh-dominant multilinguals, whose first and highproficiency "second" language is German. However, for the sake of brevity, I will use the labels "German-speakers" and "Romansh-speakers" respectively.

\section{Hypotheses and theoretical assumptions}

The assumptions and hypotheses that guide this study stem from three different areas of interest: research on language contact, spatial language typology, and second language acquisition. Due to the minority status of the Romansh language and previous studies on language contact (Weinreich, 1953; Liver, 1999; Berthele, 2006), an obvious expectation regarding the direction of crosslinguistic influence would be of the following sort (A).

A. Sursilvan displays traces of the Germanic adstratum language in its system.

On the other hand, we generally expect L1-influence on L2:

B. The German production of the Sursilvan speakers is influenced by their first (and dominant) language, i.e. Sursilvan Romansh. 
PostPrint of Berthele, R. (2012). On the Use of PUT Verbs by Multilingual Speakers of Romansh. In A. Kopecka \& B. Narasimhan (eds.), Events of "putting" and "taking": A crosslinguistic perspective., pp. 145-166. Amsterdam, Philadelphia: John Benjamins. p. 4 Although we find some sporadic instances of influence of Germanic onto Romansh in the data (cf. the discussion of example 11 below), there are good reasons to believe that the Sursilvan inventory of PUT verbs has largely resisted the influence from Germanic. The main emphasis will thus lie on hypothesis (B), and a great deal of Section 5 will address phenomena that can best be interpreted as instances of crosslinguistic influence from Sursilvan.

\section{The German and Sursilvan systems}

In this section, I attempt to describe the main characteristics of the German and Sursilvan verb lexicon in the PUT domain. In order to keep the discussion focused and concise, it will not be possible to give an exhaustive account of all possible variants and semantic constraints here. For the sake of brevity, I will also mainly focus on verbs, and the non-verbal elements will be backgrounded.

There is no doubt that German (including the Alemannic varieties spoken in Switzerland) is a satellite-framed language (cf. Talmy, 2000; Slobin, 1996, 2004; Berthele, 2004, 2006 for Swiss German and Romansh). Satellite-framed languages map the core-schema of motion in space and static spatial relations onto satellites of the verb (prefixes, adverbs, prepositions), whereas verb-framed languages map the core schema onto the verb (in the motion domain, but not necessarily in the static domain, see the discussion in Berthele, 2006: 35ff). Sursilvan, in contrast to other Romance languages, is a satellite-framed language (Berthele, 2006) as well. It is not clear yet whether this satellite-framed pattern is due to contact with German or whether it is an archaic trait of Romance languages (cf. Mair, 1984). There is good evidence (cf. Berthele, 2006: 160) that both might be the case at the same time, i.e. that Romansh displays an archaic pattern which is supported by the Germanic adstratum language.

In the related spatial domains of intransitive motion and posture it is well known that speakers of particular languages and varieties tend to prefer lexicalization patterns that map manner of motion or position onto the verb slot (cf. Slobin, 1996; Berthele, 2006). In agreement with David (2003: 3) we can consider verbs such as setzen 'to set'/ legen 'to lay'/stellen 'to stand' verbs which encode a manner component as well. We can thus ask the question whether Romansh and German emphasize the manner component in similar ways in all three related spatial domains (motion, posture, putting).

There is a conceptually as well as a diachronically motivated link from Germanic intransitive posture verbs, as in examples (1) and (2), to the characteristic Germanic PUT-verbs, as in (3) and (4). Diachronically, the latter are causative derivations with umlaut from the former (sitzen 'to sit', intr.> setzen 'to sit', trans.; liegen 'to lie'> legen 'to lay'; stehen 'to stand', intr.> stellen 'to stand', trans., cf. Grimm, 1854, vol. 16: 643). 
PostPrint of Berthele, R. (2012). On the Use of PUT Verbs by Multilingual Speakers of Romansh. In A. Kopecka \& B. Narasimhan (eds.), Events of "putting" and "taking": A crosslinguistic perspective., pp. 145-166. Amsterdam, Philadelphia: John Benjamins. p. 5
(1) die Tasse steht aufdem Tisch the cup stands on the table
(2) das Buch liegt auf dem Tisch the book lies on the table
(3) er stellt he puts-standing the cup on the table die Tasse auf den Tisch
(4) er legt das Buch aufden Tisch he puts-lying the book on the table

I assume that speakers of languages with a frequently used set of posture verbs are likely to pay attention to posture at the final state of putting-events, as expressed in the verbs setzen 'to set', legen 'to lay', stellen 'to stand' in German. As I have shown elsewhere (Berthele, 2006), Romansh is a satellite-framed language and thus similar to German with respect to the locus of the expression of path and place in the motion and posture verb domain. However, some Swiss German and all Romansh varieties do, in many ways, not display the attention to manner ("mannersaliency", cf. Slobin, 2004) that one might expect of satellite-framed languages. They rather display high frequencies of use of general verbs such as sein/esser 'to be' for posture and gehen/ir 'to go' for motion. However, despite these similar patterns found in the motion and posture verb realm, we will see that (Swiss) German and Sursilvan Romansh show fundamentally different patterns in the putting-domain.

The following discussion will mainly focus on the stimuli listed in Table 2. These stimuli represent relevant partitions of the PUT-domain for our present purposes. They have been selected on the basis of the high frequency of use of verbs such as setzen 'to set', legen 'to lay' and stellen 'to stand' and stecken 'to stick' in the German data.

As Table 2 shows clearly, the Sursilvan lexicon is less fine-grained in this domain than the German lexicon. Indeed, putting in Sursilvan is coded using the general verb metter 'to put'. There is no verb which has a complementary extension pattern such as French poser 'to put on' (vs. mettre 'to put on' and 'to put in'). There is one occasionally occurring alternative verb, tschentar, which in its intransitive variant means 'sit', and in its transitive variant 'put' (Romansh-German dictionaries typically translate the verb with "setzen/legen/stellen"). ${ }^{3}$ However, tschentar 'to put' occurs in a wide variety of responses to all kinds of stimuli, and there is no evidence for a semantic differentiation of metter 'to put' vs. tschentar 'to put'. Derungs (2005) examines the usage of this alternative to metter 'to put' 
PostPrint of Berthele, R. (2012). On the Use of PUT Verbs by Multilingual Speakers of Romansh. In A. Kopecka \& B. Narasimhan (eds.), Events of "putting" and "taking": A crosslinguistic perspective., pp. 145-166. Amsterdam, Philadelphia: John Benjamins. p. 6 and finds the highest frequency of tschentar 'to put' (4 tokens of tschentar 'to put' vs. 8 tokens of metter 'to put') for stimulus \#004 (put armload of books on table).

Table 2. Scenes referred to by the Sursilvan verb metter 'to put' and the German verbs setzen 'to set', legen 'to lay', stellen 'to stand', and stecken 'to stick'. Absolute frequencies are given in brackets*

\begin{tabular}{|c|c|c|c|}
\hline clip & Event-Type & $\begin{array}{l}\text { Sursilvan verb } \\
\text { types (tokens) }\end{array}$ & $\begin{array}{l}\text { German/Swiss German verb types } \\
\text { (tokens) (German-dominant } \\
\text { speakers only) }\end{array}$ \\
\hline 016 & $\begin{array}{l}\text { put stone into } \\
\text { pocket }\end{array}$ & $\begin{array}{l}\text { metter 'put' (12), deponer } \\
\text { deposit'(1) }\end{array}$ & $\begin{array}{l}\text { stecken 'stick' (5), versorgen 'store } \\
\text { away' (1), tun 'do' (1) }\end{array}$ \\
\hline 019 & $\begin{array}{l}\text { put stone into pot } \\
\text { of water }\end{array}$ & $\begin{array}{l}\text { metter 'put' (12), tschentar } \\
\text { 'put' (1) }\end{array}$ & legen 'put-lying' (6), tun 'do' (1) \\
\hline 003 & $\begin{array}{l}\text { put banana on } \\
\text { table with long } \\
\text { tongs }\end{array}$ & $\begin{array}{l}\text { metter 'put' (11), tschentar } \\
\text { 'put' (2) }\end{array}$ & legen 'put-lying'(6), tun 'do' (1) \\
\hline 025 & put hat on head & $\begin{array}{l}\text { metter 'put' (12), trer en 'pull } \\
\text { in'(1) }\end{array}$ & $\begin{array}{l}\text { (auf-)setzen 'put-sitting on' ( } 3) \text {, } \\
\text { legen 'put-lying' ( } 2) \text {, } \\
\text { ziehen 'pull' (2) }\end{array}$ \\
\hline 002 & $\begin{array}{l}\text { put plastic cup on } \\
\text { table with mouth }\end{array}$ & $\begin{array}{l}\text { metter 'put' (11), tschentar } \\
\text { 'put' (2) }\end{array}$ & $\begin{array}{l}\text { stellen 'put-standing' (6), tun 'do' } \\
\text { (1) }\end{array}$ \\
\hline 001 & put cup on table & $\begin{array}{l}\text { metter 'put' (10), tschentar } \\
\text { 'put' (3) }\end{array}$ & stellen 'put-standing' (7) \\
\hline 018 & $\begin{array}{l}\text { put flower into } \\
\text { hair }\end{array}$ & $\begin{array}{l}\text { metter 'put' (9), catschar } \\
\text { 'drive' (2), fermar 'fasten' (1), } \\
\text { plantar 'plant' (1) }\end{array}$ & stecken 'stick' (6), tun 'do' (1) \\
\hline 017 & $\begin{array}{l}\text { stuff rag into car } \\
\text { exhaust }\end{array}$ & $\begin{array}{l}\text { metter 'put' (6), stuppar 'stuff' } \\
(6), \text { catschar 'drive' (2), } \\
\text { smaccar 'press' (1) }\end{array}$ & $\begin{array}{l}\text { stopfen 'stuff' (4), stecken 'stick' (2), } \\
\text { schieben 'push' (1) }\end{array}$ \\
\hline
\end{tabular}

* The total amount of tokens can exceed the number of informants if some informants have provided alternative responses, and it can be less than the number of informants if one or more informants have provided unusable or no responses at all. 
PostPrint of Berthele, R. (2012). On the Use of PUT Verbs by Multilingual Speakers of Romansh. In A. Kopecka \& B. Narasimhan (eds.), Events of "putting" and "taking": A crosslinguistic perspective., pp. 145-166. Amsterdam, Philadelphia: John Benjamins. p. 7

(5) ella tschenta ils cudischs sin meisa $(\mathrm{sd} 3)^{4}$ she puts the books on table

(6) quella ha mess jeenschtes cudischs sin meisa (sd12) this.one has put a.whole.lot books on table

Stimuli such as \#025 (put a hat on head) involving putting clothing on human bodies have to be analysed carefully in our context. Firstly, there is a dialectal variation within German: whereas in Standard High German the unmarked choice for clothing is anziehen 'to put on' (or aufsetzen 'to put sth. on', only for hats; cf. (7) and (8)), in many Swiss German varieties the unmarked verb, both for clothes and hats, are cognates of anlegen 'to put on’ (cf. (9) and (10)).

(7) er zieht die Jacke an (rb0)

he pulls the coat on

(8) er setzt eine mütze auf ( $\mathrm{rb} 0)$

he sets a hat on

(9) de maa laid d jaggen aa ( $\mathrm{rb} 1)$

the man lays the coat on

(10) er läid a huet aa (rb2)

he lays a hat on

(11) el trai en ina jacca (sd5)

he pulls in a coat

Table 2 shows evidence for this variation within the responses to stimulus \#025 (put a hat on head) in the German column. Sursilvan Romansh, on the other hand, prefers metter 'to put' for these stimuli, with an occasional choice of a particle verb trer en 'to put on'(literally: 'to pull in'), whose verb root is reminiscent of Standard High German an-ziehen (literally: ‘to pull on’). Example (11) is an additional instance of this usage of the verb trer en 'to put on'. The similar usage of particle verbs trer en and an-ziehen suggests that the use of trer might be influenced by German, since other Romance languages such as French and Italian use mettre/mettere 'to put' for clothing.

German shows one variant of the common Germanic division of labour between verbs as setzen 'to set', legen 'to lay', and stellen 'to stand'. Depending on a number of factors, the main factor being the figure's final orientation, one of these three verbs is chosen. A figure (such as a cup or a book), which ends up in its canonical upright position, is usually referred to with stellen 'to stand'. It is not necessary for the figure to be taller/longer than it is wide, e.g., large (wide) bowls 
PostPrint of Berthele, R. (2012). On the Use of PUT Verbs by Multilingual Speakers of Romansh. In A. Kopecka \& B. Narasimhan (eds.), Events of "putting" and "taking": A crosslinguistic perspective., pp. 145-166. Amsterdam, Philadelphia: John Benjamins. p. 8 can still be gestellt 'put-standing' rather than gelegt 'put-lying'; a limiting case in my view is a plate, which could be both gestellt or gelegt). If the figure ends up in a non-canonical position, e.g., on its side, the verb legen 'to lay' is more adequate (e.g. a cup which is put on a table lying on its side and not standing on its base). The verb legen 'to lay' is also the primary choice for many figures that are virtually two-dimensional, or at least clearly much wider than high, even if they end up in their canonical position, e.g., a sheet of paper. The verb setzen 'to set', finally, hardly ever gets chosen in our data, with the exception of the prefixed aufsetzen 'to put on' for stimulus \#025 (put a hat on head) discussed above. German setzen ‘to set' - for inanimate figures - seems to relate to putting-events where the figure ends up in a good (but not too tight) fit situation, as in the mosaic example in (12). Setzen 'to set' with animate figures refers to the seated posture of the displaced figure at the end of the event (13).

\section{(12) er setzt den letzten Mosaikstein \\ he sets the last piece-of-a-mosaic in sein Werk into his opus \\ (13) sie setzt (a) die Katze auf das Bett she sets (a) the cat onto the bed \\ (b) das Kind auf den Stuhl \\ (b) the child onto the chair}

The last verbs that have to be briefly discussed here are stopfen 'to stuff' and stecken 'to stick' and their corresponding verbs in Sursilvan. These two German verbs both refer to the event of inserting something (partially) into a ground object. Stecken 'to stick' has a larger extension than stopfen 'to stuff'. It can be used for all kinds of configurations involving the use of more or less force on more or less flexible objects, whereas stopfen 'to stuff' - according to my intuition and as supported by the data - implies putting a flexible figure into a ground object, often achieved by a complex manipulation of the agent, and ending in a tight-fit configuration of figure and ground. 
PostPrint of Berthele, R. (2012). On the Use of PUT Verbs by Multilingual Speakers of Romansh. In A. Kopecka \& B. Narasimhan (eds.), Events of "putting" and "taking": A crosslinguistic perspective., pp. 145-166. Amsterdam, Philadelphia: John Benjamins. p. 9

(14) sie steckt derandern frau eine blume ins haar(rb5) she inserts the other:DAT women a flower in-the hair

(15) jemand stopft ein tuch in den auspuff (rb6) someone stuffs a rag into the exhaust

(16) er verstopft der uuspuff mema tüechli ( $\mathrm{rb} 2)$ he occludes the exhaust with-a rag

(17) el smacca in toc plastic el sbuf $d$ 'in auto(sd5) he squeezes a piece plastic in-the exhaust of a car

(18) el staupail sbuf cun ina servietta (sd1) he stuffs the exhaust with a napkin

(19) el metta in toc pupi el sbuf (sd13) he puts a piece paper in-the exhaust

(20) igl um catscha in toc teila el sbuf(sd2) the man presses a piece tissue in-the exhaust

Again, the Sursilvan data are characterized by the frequent choice of metter 'to put'

(19) for the stimulus involving the rag and the car exhaust (\#017, stuff rag into car exhaust, cf. Table 2). However, other verbs are used, although much less frequently than the versatile verb metter 'to put'. One of these alternative verbs is e.g., stuppar 'to stuff' (used 6 times, cf. ex. (18)). The verb stuppar is semi-cognate to German stopfen, and it is also used used parallel to the German alternation verstopfen 'to occlude'(as in example (16)). Even less frequently used verbs are catschar (ex. (20); 'drive', 'press') and smaccar (ex. (17); 'squeeze'. 
PostPrint of Berthele, R. (2012). On the Use of PUT Verbs by Multilingual Speakers of Romansh. In A. Kopecka \& B. Narasimhan (eds.), Events of "putting" and "taking": A crosslinguistic perspective., pp. 145-166. Amsterdam, Philadelphia: John Benjamins. p. 10

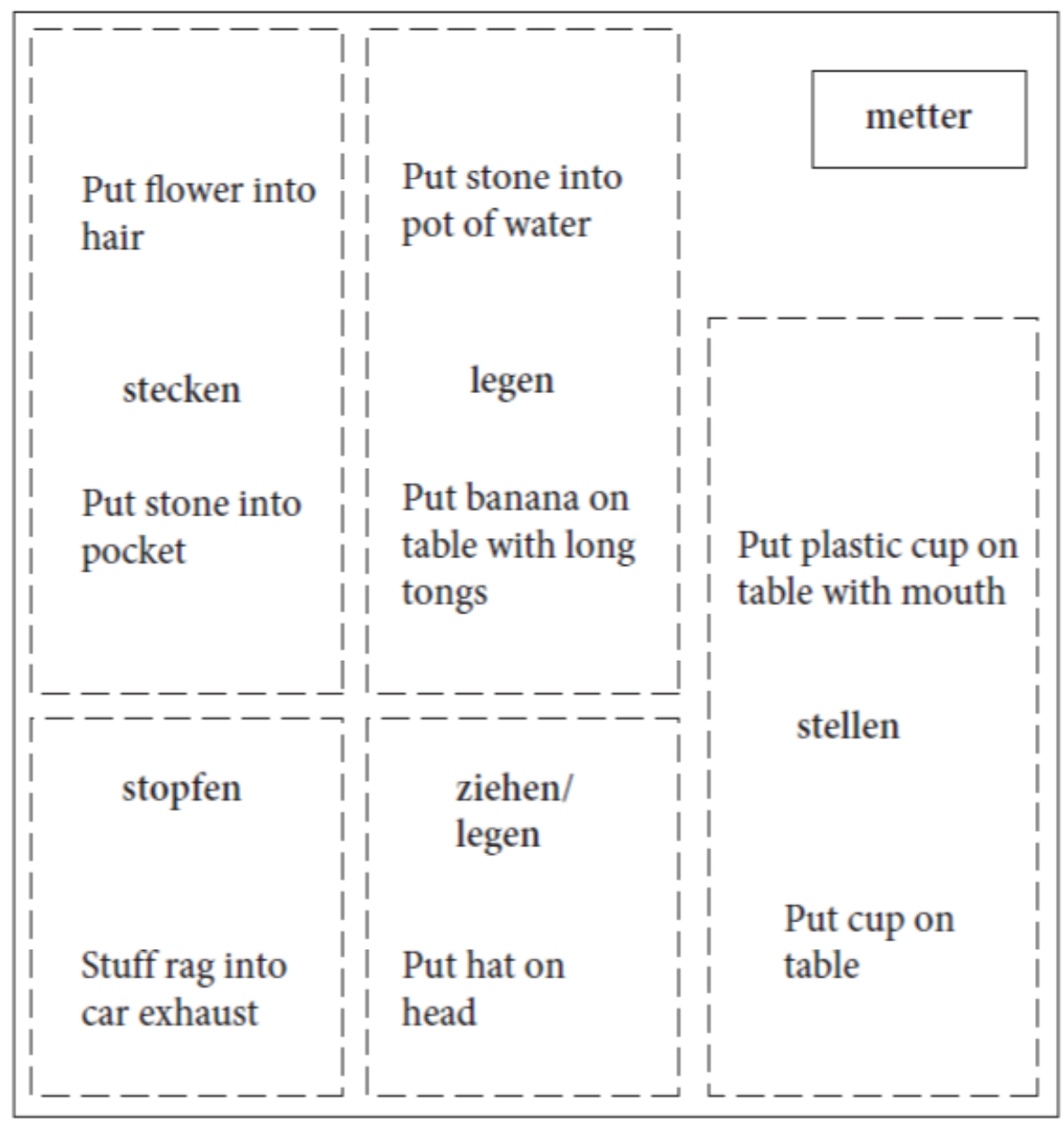

Figure 1. Romansh (solid line) and German (dashed lines) PUT-categories

On the whole, with the exception of the last stimulus discussed here, the Sursilvan data are characterized by a highly polyvalent verb metter 'to put' which can be used for a wide variety of configurations and situations (cf. Figure 1, solid line). There is no directly corresponding verb in German. German-dominant informants quite consistently chose the verb based on the semantic constraints sketched out above. However, Table 2 shows the occasional use of tun 'to do'(SG tue) in German for almost all the stimuli. In fact, the verb tun 'to do' is a widely used dummy verb in Swiss German, a verb which could cover a variety of putting events. The frequent use of relatively general verbs has been shown to be typical for some SG dialects in the realm of motion and static localization (goo, 'to go' and sii, ‘to be', see Berthele 2006: 103). In the domain of placement, we find a similar phenomenon with the verb tun 'to do'. Although there are not enough data in the sample to draw any statistically meaningful conclusions, there is no doubt that in SG, the verb tun 'to do' is a frequent and perfectly correct choice in many situations ((21)-(25), example (26) shows that tun 'to do' is also a possible choice in Standard High German). 
PostPrint of Berthele, R. (2012). On the Use of PUT Verbs by Multilingual Speakers of Romansh. In A. Kopecka \& B. Narasimhan (eds.), Events of "putting" and "taking": A crosslinguistic perspective., pp. 145-166. Amsterdam, Philadelphia: John Benjamins. p. 11

(21) d frau tuet öppis in de hosesack(rb1) the woman does something into the pocket

(22) si tuet e stäi is wasser (sd13) she does a pebble into-the water

(23) die persoon tuet öppis ins wasser (rb1) the person does something into-the water

(24) e frau tuet e banaane mit derzanga uf de tisch (rb1) a woman does a banana with the tongs onto the table e persoon tuet eneren andere e blueme ins hoor(rb1) a person does a:DAT other a flower into-the hair

(26) die frau tut einenbecherauf den tisch indem sie den becher this woman does a cup onto the table in-that she the:Acc cup zwischen den zähnen hält between the teeth holds

To sum up, there are two systems with different ways of carving up the semantic (sub-) space of putting events: a Germanic way of verbal classification distinguishing between three basic types of the figure's final state, and a Romansh (and maybe more generally: Romance) way of covering a large amount of the semantic space with a basic put-verb. Although there is variation in the data, the two general tendencies are unequivocal.

\section{The German component of the bilingual system}

As we have seen in the preceding section, learners of Sursilvan can rely on a basic category of putting all kinds of figures in all kinds of places, learners of German have to acquire different verb forms and figure out the particular semantic constraints that govern their selection. In this section, I will discuss the empirical data collected from the bilingual speakers of Sursilvan and German. Multilingual subjects, such as our speakers of Sursilvan Romansh, have, hence, to handle systems that are different.

As a general assumption, the multilingual system of the Romansh-German bilinguals is not expected to be the sum of its corresponding monolingual systems. On the contrary, mutual interdependence and influence across the subsystems is seen as the default state of any multilingual system. Thus, in a way, multilinguals have a specific competence on the one hand (Grosjean, 1985), a competence that must not be expected to be identical to the corresponding monolingual competences. On the one hand, multilinguals benefit from particular cognitive and linguistic advantages, sometimes subsumed under the term M-factor (Herdina/Jessner, 2002). On the other hand, it is a widely shared assumption in the 
PostPrint of Berthele, R. (2012). On the Use of PUT Verbs by Multilingual Speakers of Romansh. In A. Kopecka \& B. Narasimhan (eds.), Events of "putting" and "taking": A crosslinguistic perspective., pp. 145-166. Amsterdam, Philadelphia: John Benjamins. p. 12 multilingualism literature that multilinguals, from a normative point of view, are "worse speakers of the respective languages than monolingual speakers with the same educational background” (Herdina/Jessner 2002: 106).

Very generally, the different systems of Sursilvan and German (Section 4) represent different ways of categorizing putting events. An individual who carries both of these systems (or related interlanguage systems) in his/her mind thus has to cope with two different ways of looking at the same extralinguistic set of situations. If one assumes that the multilingual lexicon consists of language-specific subsystems but a shared conceptual (“semantic”) space (de Groot, 2002), then one has to understand how bi- or multilingual individuals manage to organize their respective language-specific sets of knowledge together with the overarching conceptual content.

Following Levelt (1989: 182ff.), an entry of the mental lexicon contains four different types of information:

1. semantic/conceptual information

2. syntactic information (e.g. part of speech, subcategorization, etc.)

3. phonological information

4. morphological information (e.g. inflection, ablaut phenomena, etc.)

1 and 2 form the lemma or content side (signifié) of the entry, 3 and 4 the form side (signifiant).

There are basically two ways of framing the discussion of the Romansh's German production. Firstly, their German can be construed as an L2. If this line of thought is chosen, we have to keep in mind that our informants - although they are predominantly sequential bilinguals with Romansh as their first and German as their second language (cf. Section 2) - do not acquire (Swiss) German in a "foreign-language classroom only" setup. Their German input (and output) is richer, starts in most cases in early childhood and is often more sustained in professional and sometimes even informal social contexts. A second perspective then could be to analyze the data as production data from functionally bilingual subjects, maybe with a dominant L1 Sursilvan. In the remainder of this section, both possibilities will be considered.

In the course of multilingual language acquisition, the expansion of the mental lexicon takes place in different ways, also depending on the cross-linguistic differences regarding the particular items that are acquired. Although it is not possible here to address the fundamental question of how different languages are represented and related in a multilingual's mind, there is no doubt that the data discussed below relate to the question whether the multilingual lexicon is organized via word association, concept mediation or a mixture of both of them (de Groot 2002). Table 3 lists different possible variants of cross-linguistic relations on both 
PostPrint of Berthele, R. (2012). On the Use of PUT Verbs by Multilingual Speakers of Romansh. In A. Kopecka \& B. Narasimhan (eds.), Events of "putting" and "taking": A crosslinguistic perspective., pp. 145-166. Amsterdam, Philadelphia: John Benjamins. p. 13 the form and the content side of the lexical entry (loosely following a proposition by Meissner 1993).

Although Meissner clearly talks about the acquisition of foreign languages, his taxonomy can be used as a frame of reference for relations in multiple L1 and L2 acquisition. If both form and content sides are (largely) identical, the acquisition of the new word is obviously an easy task (i), and thus the system does not have to spend too much energy to process and acquire the two forms. If the concept is identical but the phonological form is different, acquisition is still quite easy since it only involves the creation and maintenance of a new label node and its linking to an already present concept from another language (ii). This is the case for the basic spatial relation CONTAINMENT as represented by French dans 'in' and German in 'in' (Berthele 2006: 191). However, in most cases, the semantic side of either cognate (iii) or formally unrelated (v) entries does not overlap totally or not at all (iv, false friends). All of these latter cases (iii-v) require a restructuring not only of the formal side of the entry but also of the conceptual content which is associated with them. In terms of interlingual lexical economy, they are less affordable than the simpler cases of direct transfer (i) of form and content or the learning of a new label only (ii). We could thus argue, that from the point of view of learning and processing, the multilingual system has to cope with increasingly uneconomic configurations when going from type (i) to type (v) in Table 3. If the particular semantic nuances represented in the denotations of related words of type (iii) are not communicatively and pragmatically salient, one would then expect the system to simplify the crosslinguistic form-meaning relations in the sense of pattern replication as suggested by Matras (2009).

Table 3. Different degrees of crosslinguistic learning economy

\begin{tabular}{|c|c|c|c|}
\hline & $\begin{array}{l}\text { identity on the } \\
\text { signifiant side }\end{array}$ & $\begin{array}{l}\text { identity on the } \\
\text { signifier side }\end{array}$ & example \\
\hline (i) & yes & yes & Fr. $\dot{a} \sim$ It. $a$ 'at, on' \\
\hline (ii) & no & yes & Fr. dans $\sim$ Germ. in 'in' \\
\hline (iii) & yes & partial & $\begin{array}{l}\text { Fr. libéral } \neq \\
\text { Eng. liberal }\end{array}$ \\
\hline (iv) & yes & no & $\begin{array}{l}\text { Ger. eventuell } \neq \\
\text { Engl. eventually }\end{array}$ \\
\hline (v) & no & partial & $\begin{array}{l}\text { Rom. metter 'to put' } \\
\approx \text { Ger. stellen 'to put-standing', legen 'to } \\
\text { put-lying', [...] }\end{array}$ \\
\hline
\end{tabular}


PostPrint of Berthele, R. (2012). On the Use of PUT Verbs by Multilingual Speakers of Romansh. In A. Kopecka \& B. Narasimhan (eds.), Events of "putting" and "taking": A crosslinguistic perspective., pp. 145-166. Amsterdam, Philadelphia: John Benjamins. p. 14 In L2 acquisition, following Jiang's (2000) proposal, we can distinguish three stages of acquisition of a new lexeme:

Whereas the phonological form entry gets acquired relatively fast, the lemma can linger for a certain amount of time in a transitional intermediate stage until it is replaced by the target language semantics and syntax. However, as Jiang (2000: 54) argues, especially in tutored language learning, many learners do not go beyond the

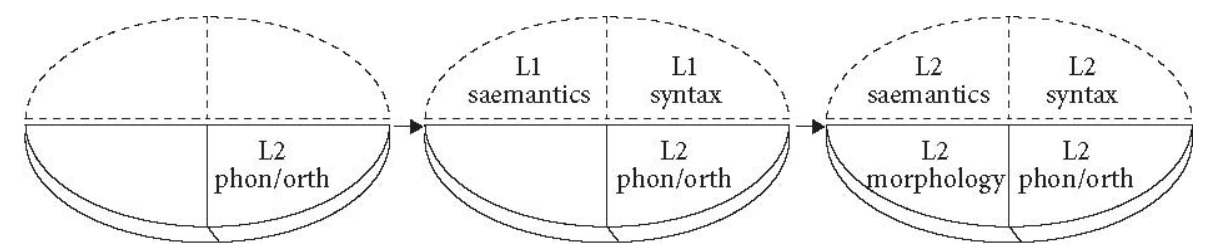

Figure 2. Three stages of vocabulary acquisition in L2 (from Jiang 2000: 54)

second stage. Since the lemma side of L1 mediates more or less successfully between the L2 form and the conceptual domain, the processor reinforces the connection between the L1-lemma and the L2 form and pays less attention to the input that provides the information necessary to restructure the semantic category towards the category that is actually valid in the (monolingual/fully mastered) L2. This, according to Jiang (2000), gives rise to the frequently observable state in which learners fossilize at the "lemma mediation stage" despite their sustained exposure to rich and contextualized input.

Let us now analyse the German production of the bilingual speakers of Sursilvan Romansh. Examples (27)-(33) show pairs of responses (a) and (b) by the same informants in Romansh and German respectively. In each of these examples, the response in (c) shows the dominant verb choice given by a monolingual German informant. 
PostPrint of Berthele, R. (2012). On the Use of PUT Verbs by Multilingual Speakers of Romansh. In A. Kopecka \& B. Narasimhan (eds.), Events of "putting" and "taking": A crosslinguistic perspective., pp. 145-166. Amsterdam, Philadelphia: John Benjamins. p. 15

(27) clip \#002 (put plastic cup on table with mouth)

a. ella metta giu in cup culla bucca sin meisa (sd9) she puts down a cup with-the mouth on table

b. di frau laid de becher uf em tisch (sd9) this woman puts-lying the cup on the:DAT table

c. e frau stell mit em muul en becher ufe tisch (rb1) a woman puts-standing with the mouth a cup on-the:ACc table

(28) clip \#025 (put hat on head)

a. El metta si capetscha. (sd4) he puts on hat

b. Der Student legt die Mütze auf den Kopf. (sd4) the student puts-lying the hat on the head

c. en maa laid e kchappan a (rb1) a man puts-lying a hat on

(29) clip \#019 (put stone into pot of water)

a. ina persuna metta quei toc crap ell'aua ( $\mathrm{sd} 2$ ) a person puts this piece stone in-the water

b. dia frau stellt an stai ins wasser ( $\mathrm{sd} 2)$ this woman puts a stone in-the:ACC water

c. öpper laid en stai $i$ de topf wasser (rb3) someone puts-lying a stone in the:ACC pot water

(30) clip \#016 (put stone into pocket)

a. ella metta in crap en sac (sd1) she puts a rock in pocket 
PostPrint of Berthele, R. (2012). On the Use of PUT Verbs by Multilingual Speakers of Romansh. In A. Kopecka \& B. Narasimhan (eds.), Events of "putting" and "taking": A crosslinguistic perspective., pp. 145-166. Amsterdam, Philadelphia: John Benjamins. p. 16
b. Sie legt einen Stein in den Hosensack. (sd1) she puts-lying a stone in the:ACC pocket
c. si steckt öppis in der hosesack (rb2) she tucks something in the:ACC pocket

(31) clip \#003 (put banana on table with long tongs)

a. ella metta giu la banana sin meisa (sd10) she puts down the banana onto table

b. sie setzt die banane mit der zange auf dem tisch (sd10) she puts-sitting the banana with the tongs on the:DAT table

c. si laid a banana uf der tisch mit ara zanga (rb2) she puts-lying a banana on the:ACC table with a tong

(32) clip \#001 (put cup on table)

a. Ella ha mess la scadiola sin meisa. (sd12) she has put the bowl on table

b. die persoon laid d tassen uf de tisch (sd12) this person puts-lying the cup on the:Acc table

c. si stellt e tassa uf de tisch ( $\mathrm{rb} 2)$ she puts-standing a cup on the:ACc table

clip \#018 (put flower into hair)

a. ella ha semudergiau da metter quella flur els cavels alla dunna (sd12) she has strived to put this flower in-the hairs of-the woman

b. die persoon laid e blueme i de hoor ( $(\mathrm{d} 12)$ this person puts-lying a flower in the:DAT hair

c. si steckt a bluemen ins hoor (rb2) she sticks a flower in-the:ACC hair

All examples, in their (b) entry, share one important feature: a choice of put-verb which can never be found in the monolingual German data, and which in all cases sounds odd to native speakers (regardless of whether they are speakers of Swiss or Standard High German). E.g., the verb legen 'to lay' is impossible for a flower inserted into a woman's hair (example (33)). Moreover, the scene with the cup on the table (\#001, cf. Table 2) would be referred to using the verb stellen 'to stand' (example (32)). The verb legen 'to lay' could only be used if it ended up in a noncanonical position on its side, and the same is true for stimulus \#002 (put plastic cup on table with mouth, example (27)). 
PostPrint of Berthele, R. (2012). On the Use of PUT Verbs by Multilingual Speakers of Romansh. In A. Kopecka \& B. Narasimhan (eds.), Events of "putting" and "taking": A crosslinguistic perspective., pp. 145-166. Amsterdam, Philadelphia: John Benjamins. p. 17 Clip \#025 (put a hat on head, example (28)) refers to a special case: as already mentioned above, Swiss German uses a verb of the type an-legen (alegge, 'to put on') for hats, as opposed to an-ziehen/auf-setzen ‘to put on' in SHG. The salient feature in the SHG production of informant sd4 is that the equivalent of the Swiss German verb is used in SHG (although by omitting the obligatory particle -an). This can often be observed in Swiss German children learning SHG.

Obviously, the examples above have been carefully chosen in order to demonstrate deviating choices of the speakers of Sursilvan in German. Oftentimes the informants use the same verbs as the monolingual German-speaking informants do. But the alternative (and, from a monolingual point of view: incorrect) choices are quite frequent in the German data produced by the Sursilvan speakers. Figures 3 and 4 compare the different choices of verbs across the group of German L1 and German L2 speakers. The figures represent only the stimuli from Table 2 with a clear preference for Sursilvan metter 'to put', the responses to stimulus \#017 (stuff rag into car exhaust) have thus been excluded from the analysis.

As Figures 3 and 4 show, there are sometimes important differences between choices made by native speakers and those made by plurilingual speakers of Sursilvan. These differences are mostly due to the choice of "wrong" verbs as illustrated in examples (27b)-(33b) above. The dummy verb tun 'to do', which is perfectly fine in Swiss German, is chosen more frequently than in the corresponding monolingual Swiss German data. This is the most economic way of transferring the metter ‘to do’ category into Swiss German. 
PostPrint of Berthele, R. (2012). On the Use of PUT Verbs by Multilingual Speakers of Romansh. In A. Kopecka \& B. Narasimhan (eds.), Events of "putting" and "taking": A crosslinguistic perspective., pp. 145-166. Amsterdam, Philadelphia: John Benjamins. p. 18

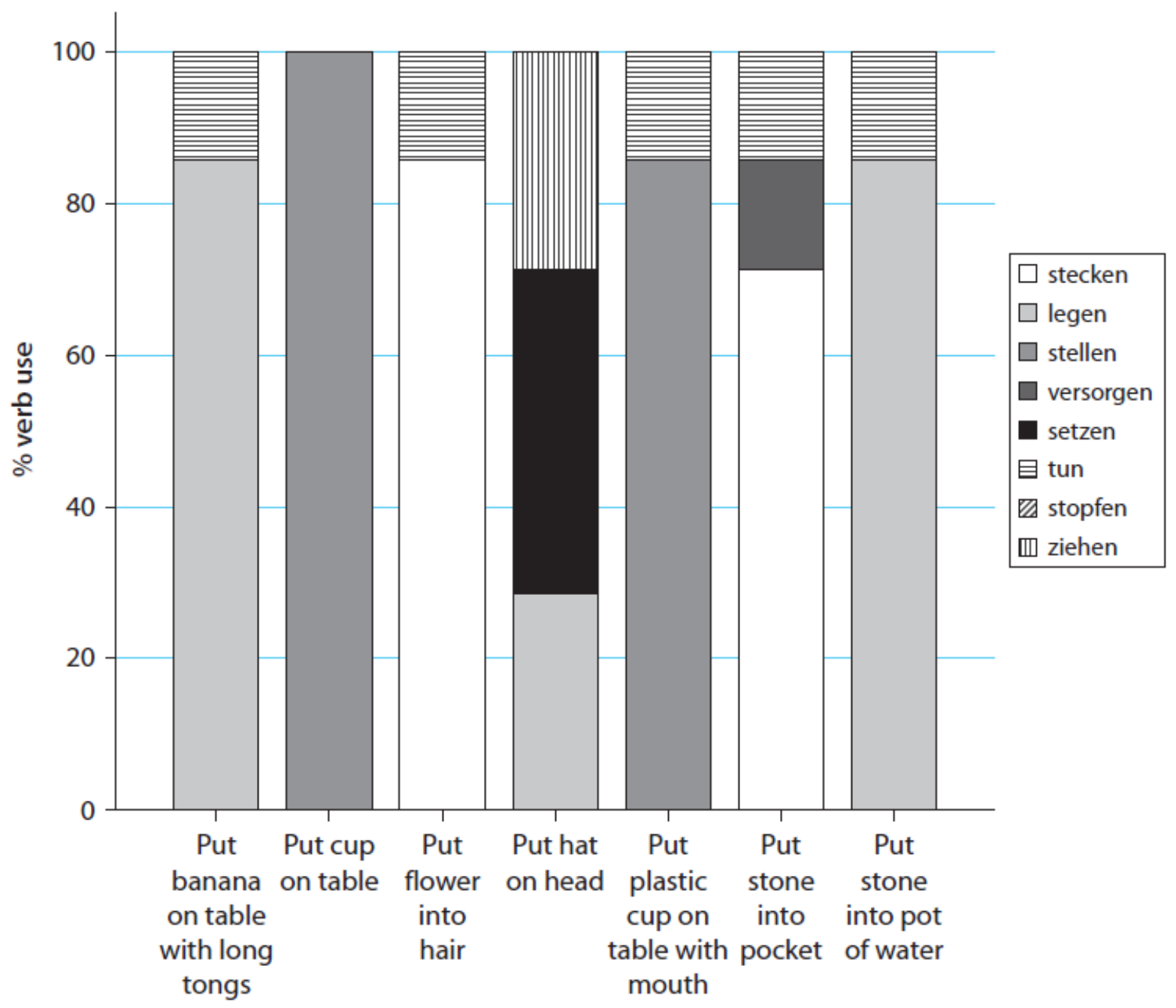

Stimulus

Figure 3. Selected stimuli and verb types used by monolingual speakers of German 
PostPrint of Berthele, R. (2012). On the Use of PUT Verbs by Multilingual Speakers of Romansh. In A. Kopecka \& B. Narasimhan (eds.), Events of "putting" and "taking": A crosslinguistic perspective., pp. 145-166. Amsterdam, Philadelphia: John Benjamins. p. 19

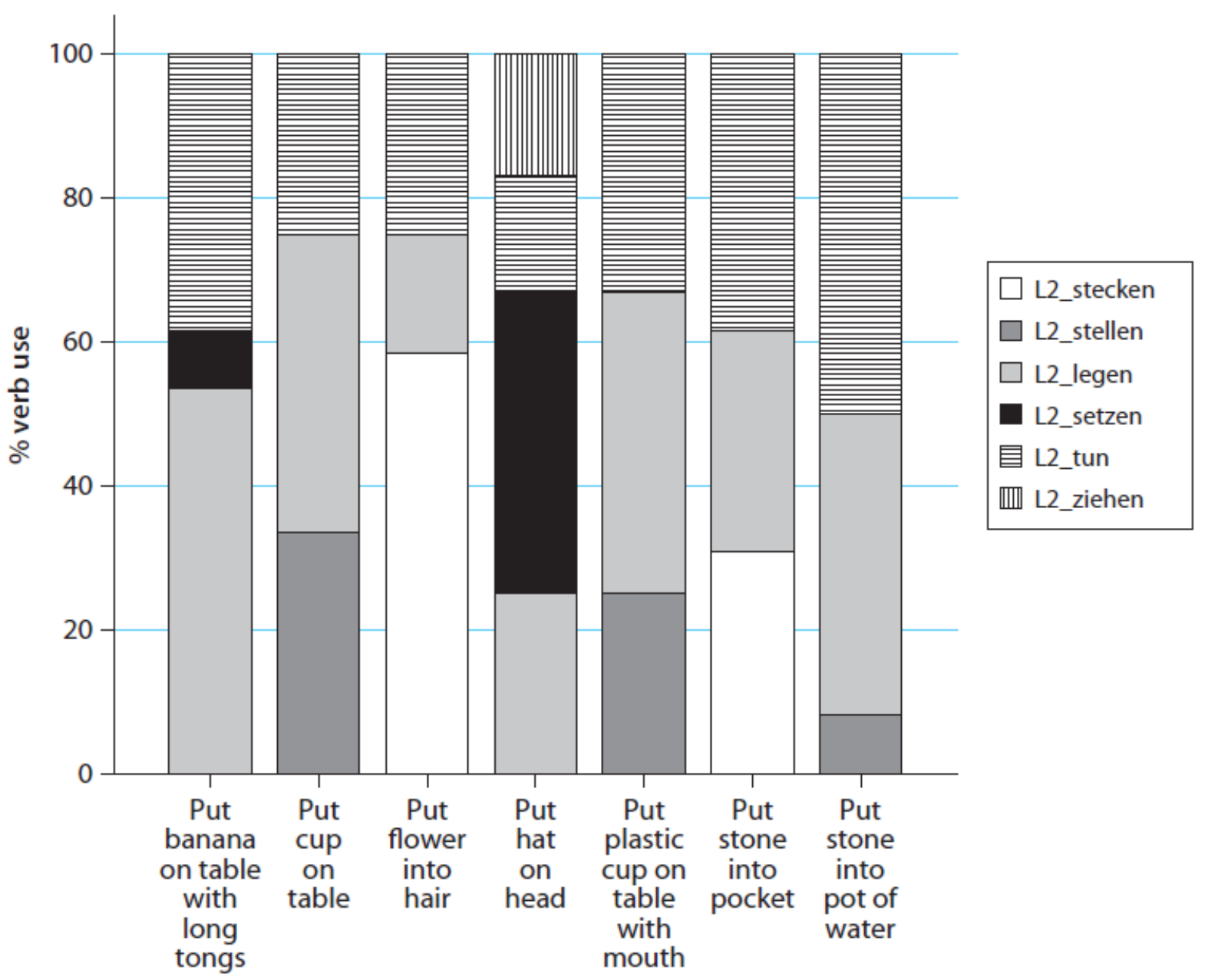

Stimulus

Figure 4. Selected stimuli and verb types used by the Romansh bilinguals speaking German 
PostPrint of Berthele, R. (2012). On the Use of PUT Verbs by Multilingual Speakers of Romansh. In A. Kopecka \& B. Narasimhan (eds.), Events of "putting" and "taking": A crosslinguistic perspective., pp. 145-166. Amsterdam, Philadelphia: John Benjamins. p. 20

Table 4. "Wrong" verb choices and choices of the tun-strategy in responses to 8 placement scenes

\begin{tabular}{lcccc}
\hline speaker & \multicolumn{3}{c}{ wrong use of... } & choices of \\
& legen 'to putlying' & setzen 'to put standing' & stellen 'to put standing' & \\
\hline sd1 & 4 & 0 & 0 & 0 \\
sd2 & 2 & 0 & 1 & 0 \\
sd3 & 2 & 0 & 0 & 0 \\
sd4 & 2 & 0 & 0 & 0 \\
sd5 & 2 & 0 & 0 & 0 \\
sd6 & & no German data available & \\
sd7 & 0 & 0 & 0 & 6 \\
sd8 & 0 & 0 & 0 & 5 \\
sd9 & 0 & 0 & 0 & 4 \\
sd10 & 1 & 1 & 1 & 8 \\
sd11 & 0 & 0 & 0 & 0 \\
sd12 & 5 & 0 & 0 & 3 \\
sd13 & 0 & 0 & 0 & \\
\hline
\end{tabular}

Obviously, the Sursilvan speakers show a certain degree of deviant use of German verbs. There are different competing verbs, as opposed to the native speakers of German who clearly show preferences for one particular verb per scene. Figure 4 shows not only a higher degree of variation, but also that the use of legen 'to lay' is generalized and covers scenes which are not referred to by legen 'to lay' in the monolinguals' responses (put cup/plastic cup on table, stone into pocket). A similar overgeneralization of the verb leggen 'to lay' has also been found in Dutch L1 acquisition in 4- and 5-years old children (Narasimhan \& Gullberg 2011). They note that the factor of input frequency can be ruled out since zetten 'to set' is much more frequent in the input than leggen 'to lay'. We might tentatively hypothesize that legen/leggen 'to lay' somehow seems to have a more basic or unmarked denotation, but this remains a matter of speculation and our current data do not allow any further conclusions.

If we look at the individual speaker's choices (Table 4), we discover that 7 informants extend the use of the verb legen 'to lay' to cover "wrong” situations (compared to the monolingual's production; cf. Section 4 for the rationale 
PostPrint of Berthele, R. (2012). On the Use of PUT Verbs by Multilingual Speakers of Romansh. In A. Kopecka \& B. Narasimhan (eds.), Events of "putting" and "taking": A crosslinguistic perspective., pp. 145-166. Amsterdam, Philadelphia: John Benjamins. p. 21 regarding the scene selection). In two cases (sd1 and sd12), this overextension is reflected clearly by the absolute number of choices. Table 4 shows also the other strategy chosen by another group of speakers, namely the frequent use of tun 'to do’ for many (sd7, sd8, sd9, sd10, and, to a lesser extent, sd13) or even all (sd11) scenes. Note also that almost all informants fall into either the legen- or into the tun-group, only sd10 shows both wrong uses of the German verbs and the 'tunstrategy'.

Table 4 suggests a somewhat refined interpretation of the data: most of the Romansh speakers try to reconstruct a "German” parallel to their L1 semantic pattern. Either they overextend the use of legen 'to lay' to cover a variety of events in a way that is different from the German speakers' production, or they choose to use the correct alternative German dummy verb tun 'to do'. The latter strategy allows them to avoid the choice of the potentially inappropriate (from the monolingual, normative point of view) item in the German set of verbs of putting. This choice can be interpreted as a consequence of convergence in a language contact situation, but also, as some informants explicitly comment after the task, as a conscious strategy of avoidance due to linguistic insecurity.

In terms of Jiang's model of L2 lexical acquisition (Figure 2), we can certainly assume that the Romansh did acquire the L2 forms setzen, legen, stellen 'to stand' (and other verbs from the put domain), since these verbs are frequent in German, not only in spatial language but also in non-spatial phrasal constructions as in “jemandem eine Frage stellen” (ask a question), “jemandem etwas zur Verfügung stellen” (to allocate, provide sth.), “etwas zu Grunde legen” (to form the basis of sth). Jiang claims that in the second stage, morphology is not yet acquired. This is certainly not the case for our speakers: their verbal morphology is acquired (even for irregular verbs such as legen 'to lay'), and there is not a single token in the data that does not show correct SG verbal morphology. This is not so surprising, given the aforementioned high frequency of the lexeme in all kinds of constructions. What is not achieved at this stage is the spatial semantic category of these verbs. The semantics of setzen 'to set', legen 'to lay' and stellen 'to stand' are obviously not differentiated in the way it is in German L1 speakers. The conceptual content associated with these lexical entries may well be related to the concepts covered by metter 'to put', but the bilingual speakers' use of these verbs reveals that they do not carve up the semantic space in the same way that monolingual native Germans do. Those informants who overextend legen 'to lay' chose one verb out of the three to cover large portions of the putting-events, and those who go for the tun-strategy merge the semantic metter-category with the large portion of semantic space that is covered by tun 'to do'. Both strategies avoid the restructuring of the semantic space towards the German way, while the tun-strategy obviously has the advantage of being correct (although stylistically marked as colloquial) in the target-language. As an alternative to the L2-acquisition oriented account we could also refer to Muysken’s (2000: 277) processing economy principle: 
PostPrint of Berthele, R. (2012). On the Use of PUT Verbs by Multilingual Speakers of Romansh. In A. Kopecka \& B. Narasimhan (eds.), Events of "putting" and "taking": A crosslinguistic perspective., pp. 145-166. Amsterdam, Philadelphia: John Benjamins. p. 22 Suppose we have two separate grammars that have to be processed by one system. It is conceivable that there is a uniformizing tendency resulting from the processing system, tending towards one superficial word order for both languages, etc. Muysken (2000: 277)

If we extend this principle to the semantic domain, we could argue that there is a "uniformizing" tendency to assume one-to-one relationships between conceptually "equivalent" morphemes of the bi- or multilingual lexicon. This assumption could lead to the observed deviances from monolingual use of put-verbs. One should also keep in mind that the semantic differentiations provided by the German verbs are informationally and communicatively hardly ever salient; in other words, a language can perfectly well do without such verbal classificatory systems. The mechanism described on the basis of Jiang's (2000) model simply provides a possible acquisition rationale which might reflect the mechanism underlying conceptual convergence due to semantic economy in highly proficient bilinguals.

The strategy of extending one verb to have it comply with the L1-category (as in metter 'to put') has been observed in other contexts. Melin-Köpilä (1996) reports that the Swedophone minority in Finland has chosen one verb (sätta 'to set') to correspond to the Finnish verb panna 'to put' which seems to cover the whole put domain just as metter ‘to do’ in Sursilvan Romansh does:

\section{(34) han satte böckerna i väskan he puts-seated books-the into bag-the}

If the majority-minority balance in the Romansh areas was inverted, i.e. if the German-speaking were a minority, and the Romansh the majority, this would be the kind of language change we would expect in German. However, since things are the other way around, the phenomenon of the overextension of legen 'to lay' is not considered language change, but rather an instance of convergence and pattern replication (Matras, 2009: 245) within bilingual speakers.

\section{Conclusions}

The data discussed in this paper show that although Romansh subjects are fluent speakers of German (and in some cases even assert that they are more at ease in German than in Romansh), their plurilingual competence shows particularities which distinguishes them from the idealized "double monolinguals". The frequent instances of crosslinguistic influence of German in the Romansh language (cf. e.g., Weinreich, 1953) have not been the main focus of this contribution. On the contrary, the data discussed here show the influence of Romansh in the German production of our subjects. This finding seems to suggest a considerable amount of ethnolinguistic vitality of the Sursilvan language despite its status as a threatened language. At first sight, the German competence of the multilingual subjects could 
PostPrint of Berthele, R. (2012). On the Use of PUT Verbs by Multilingual Speakers of Romansh. In A. Kopecka \& B. Narasimhan (eds.), Events of "putting" and "taking": A crosslinguistic perspective., pp. 145-166. Amsterdam, Philadelphia: John Benjamins. p. 23 be understood as an "approximative system” (Nemser, 1971; cf. also Herdina/Jessner, 2002: 45), i.e. a system whose proficiency, compared to the idealized native speaker proficiency, shows "fossilization" at a slightly lower level. However, I have argued in Section 5, that, from the point of view of a multilingual system with high proficiencies in at least two languages, one could also understand the "wrong" verb choices as an entailment of a hypothesized extension of Muysken’s processing economy principle to the semantic domain.

The semantic distinctions reflected in German verbs such as setzen 'to set', legen 'to lay', and stellen 'to stand' are, from a pragmatic or interactive point of view, negligible. From a communicative point of view, there is relatively little added value in the obligatory expression of setting, standing and laying each time an event of PUTTING is expressed. Languages that carry along such verbs in some sense preserve 'linguistic luxury'. This particular luxury feature of German has not been acquired in a native-like way by the multilingual speakers of Romansh examined in this chapter. On the other hand, the correct (monolingual) use of these verbs does convey sociolinguistic meaning: Since the general expectation (even among linguists) is that the Romansh are "perfect" bilinguals, they have adopted themselves this unrealistic point of view and feel extremely embarrassed to realize that their German, in certain respects, is "bad". As in many other minority language contexts, many Romansh have a split loyalty regarding their native language: on the one hand they feel that this is their real mother tongue, but on the other hand they realize that virtually all socio-economic opportunities require high proficiency in German. Thus, many Romansh want their children to go to German-speaking schools, and the resistance regarding bilingual schooling is often stronger in the Romansh families than in the German-speaking families. In my view, this split loyalty can be related to the two strategies described in Section 5: the use of the dialectal dummy-verb tue 'to do' would be the most economic solution since it allows a direct transfer of the metter-category into German. But the speakers of Romansh realize that, especially in the "good" (=standard) language, there are these other verbs that are preferred. So they attempt to acquire them, but due to the characteristics of the dynamic multilingual system, this acquisition leads to converging patterns instead of a "perfect” replication of the German adstratum language norms.

\section{Notes}

1. Many thanks to Silvana Derungs for collecting the Sursilvan Data. Thanks also to Irmi Kaiser and to two anonymous reviewers for comments on earlier versions of this chapter.

2. Indeed, the Romansh informants in our sample, when speaking German, are not readily identifiable as speakers of Romansh by a native Swiss German, unless he or she is a linguist or language teacher and pays attention to nuances such as those laid out in the sections below. 
PostPrint of Berthele, R. (2012). On the Use of PUT Verbs by Multilingual Speakers of Romansh. In A. Kopecka \& B. Narasimhan (eds.), Events of "putting" and "taking": A crosslinguistic perspective., pp. 145-166. Amsterdam, Philadelphia: John Benjamins. p. 24 3. One explanation for the occasional use of this verb is that informants are looking for near synonyms in order to vary their production during the quite monotonous task of describing the PUT-stimuli.

4. The informants' identification labels are given in brackets. Examples without this informant tag are made up examples.

\section{References}

Berthele, R. 2004. The typology of motion and posture verbs: A variationist account. In Dialectology Meets Typology, B. Kortmann (ed.), 93-126. Berlin: Mouton de Gruyter.

Berthele, R. 2006. Ort und Weg. Eine vergleichende Untersuchung der sprachlichen Raumreferenz in Varietäten des Deutschen, Rätoromanischen und Französischen. Berlin: Mouton de Gruyter.

Bowerman, M., Gullberg, M., Majid A. \& Narasimhan, B. 2004. Put project: The crosslinguistic encoding of placement events. In Field Manual, Vol. 9, A. Majid (ed.), 10-24. Nijmegen: Max Planck Institute for Psycholinguistics.

Cathomas, R. 2005. Schule und Zweisprachigkeit. Immersiver Unterricht: Internationaler Forschungsstand und eine empirische Untersuchung am Beispiel des rätoromanisch-deutschen Schulmodells. Münster: Waxman.

David, C. 2003. Les ‘verbs of putting’: Typologie, schéma syntaxique et organisation sémantique. Poitiers: Université de Poitiers.

de Groot, A. 2002. Lexical representation and lexical processing in the L2 user. In Portraits of the L2 User, V. Cook (ed.), 32-63. Clevedon: Multilingual Matters.

Derungs, S. 2005. Eveniments da deplazzament el romontsch sursilvan. Fribourg: Universitad da Friburg, Linguatg e litteratura rumantscha.

Furer, J.-J. 1985. Romanche - Du bilinguisme à la fin de la discrimination. Laax: Fundaziun retoromana.

Grimm, J. \& Grimm, W. 1854-1971. Deutsches Wörterbuch von Jacob und Wilhelm Grimm. Leipzig: S. Hirzel.

Grosjean, F. 1985. The bilingual as a competent but specific speaker-hearer. Journal of Multilingual and Multicultural Development 6: 467-477. 
PostPrint of Berthele, R. (2012). On the Use of PUT Verbs by Multilingual Speakers of Romansh. In A. Kopecka \& B. Narasimhan (eds.), Events of "putting" and "taking": A crosslinguistic perspective., pp. 145-166. Amsterdam, Philadelphia: John Benjamins. p. 25 Herdina, P. \& Jessner, U. 2002. A Dynamic Model of Multilingualism.

Perspectives of Change in Psycholinguistics. Clevedon: Multilingual Matters.

Jiang, N. 2000. Lexical representation and development in a second language. Applied Linguistics

21: 47-77. Levelt, W.J. 1989. Speaking. From Intention to Articulation. Cambridge MA: The MIT Press. Liver, R. 1999. Rätoromanisch. Eine Einführung in das Bündnerromanische. Tübingen: Narr. Mair, W.N. 1984. Transferenz oder autonome Bildung? Bemerkungen zum Problem der Par

tikelverben im Ladinischen, Friulanischen, Italienischen und Französischen. Zeitschrift für

romanische Philologie 100: 408-432.

Matras, Y. 2009. Language Contact. Cambridge: Cambridge University Press.

Meissner, F.-J. 1993. Interlexis - ein europäisches Register und die Mehrsprachigkeitsdidaktik

(Französisch/Spanisch). Die Neueren Sprachen 92: 532-554.

Melin-Köpilä, C. 1996. Om normer och normkonflikter i finlandsvenskan. Språkliga studier med utgångspunkt i nutida elevtexter. Uppsala: Uppsala universitet.

Muysken, P. 2000. Bilingual Speech: A Typology of Code-mixing. Cambridge: Cambridge University Press.

Narasimhan, B., \& Gullberg, M. 2011. The role of input frequency and semantic transparency in the acquisition of verb meaning: Evidence from placement verbs in Tamil and Dutch. Journal of Child Language, 38, 504-532.

Nemser, W. 1971. Approximative systems of foreign language learners. International Review of Applied Linguistics 9: 115-123.

Romaine, S. 1995. Bilingualism. 2nd edn. Oxford: Blackwell.

Slobin, D. 1996. Two ways to travel: Verbs of motion in English and Spanish. In Grammatical Constructions: Their Form and Meaning, S. Thompson \& M. Shibatani (eds), 195-217. Oxford: OUP.

Slobin, D. 2004. The many ways to search for a frog: Linguistic typology and the expression of motion events. In Relating Events in Narrative: Typological and 
PostPrint of Berthele, R. (2012). On the Use of PUT Verbs by Multilingual Speakers of Romansh. In A. Kopecka \& B. Narasimhan (eds.), Events of "putting" and "taking": A crosslinguistic perspective., pp. 145-166. Amsterdam, Philadelphia: John Benjamins. p. 26 Contextual Perspectives, S. Strömqvist \& L. Verhoeven (eds), 219-257. Mahwah NJ: Lawrence Erlbaum Associates.

Solèr, C. 1997. Rätoromanische Schweiz. In Contact Linguistics: An International Handbook of Contemporary Research, H. Goebl, P. Nelde, Z. Starý \& W. Wölk (eds), 1879-1886. Berlin: Mouton de Gruyter.

Talmy, L. 2000. Toward a Cognitive Semantics, Vol. II: Typology and Process in Concept Structuring. Cambridge MA: The MIT Press.

Weinreich, U. 1953. Languages in Contact. Findings and Problems. New York NY: Publications of the Linguistic Circle of New York. 